\title{
ERRATUM
}

Jari Mäkinen · Hannu V. Makkonen

\section{Petrology and structure of the Palaeoproterozoic (1.9 Ga) Rytky nickel sulphide deposit, Central Finland: a comparison with the Kotalahti nickel deposit}

Published online: 29 October 2004

(C) Springer-Verlag 2004

\section{Mineralium Deposita (2004) 39:405-421}

A program error caused a mistake in the plotting in Fig. 9. The correct Fig. is shown here.

Fig. 9 Olivine nickel vs. Fo. The model curves show the composition of the olivine crystallising from the proposed parent tholeiite given different mass ratios between the silicate melt and sulphide melt $(R)$. R values are calculated after Campbell and Naldrett (1979), using the following equations: $\log \mathrm{MgO}_{\mathrm{Liq}}=(\log \mathrm{Fo}-\log$ $(252.7833-0.7825 * \mathrm{Fo}))$ $0.4602+1.795$ and $\mathrm{MgO}_{\mathrm{Liq}}=$ $0.2588 \sqrt{ }\left(0.9554 /\left(100 / \mathrm{Fo}_{0}-0.67\right)\right)$

(Makkonen 1996), $\mathrm{Ni}_{\mathrm{Liq}}=$ $2.1257^{*} \mathrm{MgO}_{\text {Liq }}{ }^{\wedge} 2.05$ (modified after Makkonen 1996),

$\mathrm{D}_{\mathrm{Ni}} \mathrm{OL} / \mathrm{Liq}=\mathrm{e}^{\wedge}(4.961-$

$\left.1.266 * \ln \mathrm{MgO}_{\mathrm{Liq}}\right)($ Duke and Naldrett 1978), $\mathrm{D}_{\mathrm{Ni}}{ }^{\text {sul/sil }}=$ 350 (Francis 1990)

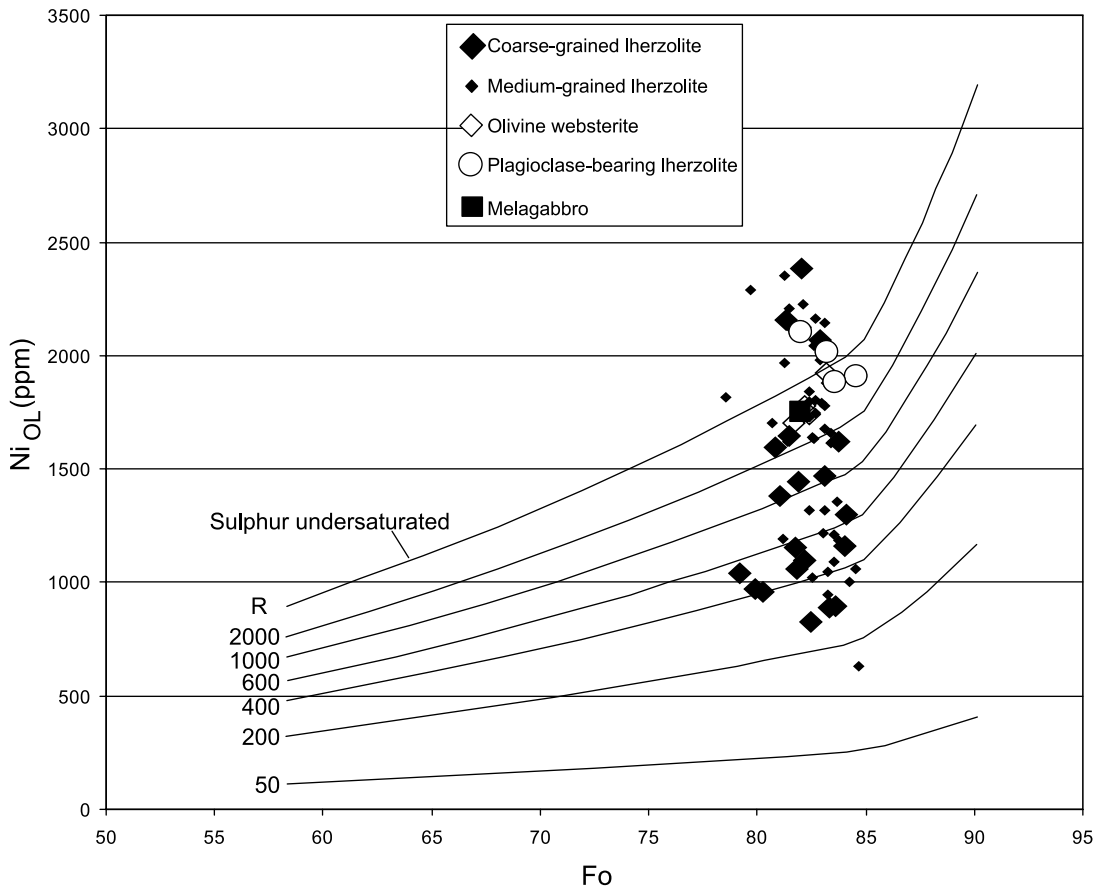

The online version of the original article can be found at http:// dx.doi.org/10.1007/s00126-004-0413-4

J. Mäkinen $(\varangle) \cdot$ H. V. Makkonen

Geological Survey of Finland, P. O. Box. 1237,

70211 Kuopio, Finland

E-mail: jari.makinen@gsf.fi

Tel: + 358-20-5503535

Fax: + 358-20-55013

E-mail: hannu.makkonen@gsf.fi 